\title{
THE IMPORTANCE OF THE PRECHTL METHOD FOR ULTRA-EARLY PREDICTION OF NEUROLOGICAL ABNORMALITIES IN NEWBORNS AND INFANTS
}

\author{
Dragan Zlatanović1,2, Hristina Čolović1,2, Vesna Živković1,2, Mirjana Kocić1,2,

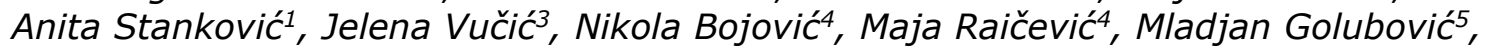 \\ Ljubomir Dinić6, Tamara Stanković
}

\begin{abstract}
Early detection of cerebral palsy and minimal neurological deficit symptoms in newborns and infants is of crucial importance since it enables timely inclusion of children in neurodevelopmental treatment which contributes to the improvement of motor functional status at a later age, taking into account a biological phenomenon known as "brain plasticity". Conventional methods of neurological assessment of newborns and infants include neurological examination, quantitative assessment of motor functions using scales and tests, and utilization of additional diagnostic neuroimaging procedures as well. All the aforementioned methods are absolutely necessary for wider use in clinical practice as well. They enable fast diagnosis of neurological disorders and fast detection of central nervous system impairments, but they also share a common defect - inability of making adequate prognosis of neurological deficits. Thanks to Prechtl's Method based on qualitative assessment of spontaneous motor activity, specific neurological patterns that are excellent predictors of a child's neurological development can be defined even in the prenatal stage, as well as after birth in preterm and term newborns. The aim of the paper is to review literature data on the possibilities and importance of Prechtl's method in comparison to other conventional methods for ultra-early identification of newborns and infants at risk of the development of permanent neurological deficit - cerebral palsy and/or minimal neurological dysfunction.

Prechtl's method is the most sensitive and specific clinical diagnostic procedure for the assessment of future neurological outcomes in high-risk newborns and infants.
\end{abstract}

Acta Medica Medianae 2019;58(3):111-115.

Key words: newborn, infant, spontaneous motor activity, early diagnosis, cerebral palsy, Prechtl's method

\author{
${ }^{1}$ Clinic of Physical Medicine and Rehabilitation, Clinical Centre \\ Niš, Serbia \\ ${ }^{2}$ Faculty of Medicine, University of Niš, Serbia \\ ${ }^{3}$ Clinic of Pediatrics, Clinical Centre Niš, Serbia \\ ${ }^{4}$ Clinic for Pediatric Surgery and Orthopedics, Clinical Centre \\ Niš, Serbia \\ ${ }^{5}$ Clinic of Anesthesiology and Reanimatology, Clinical Centre \\ Niš, Serbia \\ ${ }^{6}$ Clinic of Urology, Clinical Centre Niš, Serbia \\ ${ }^{7}$ Center of Nuclear Medicine, Clinical Center Niš, Serbia
}

Contact: Dragan Zlatanović

Učitelj Tasa 25/3, 18000 Niš, Serbia

E-mail: dragan.zlatanovic@medfak.ni.ac.rs draganzlatanovic1@gmail.com

\section{Introduction}

Motor development of newborns and infants is completely spontaneous according to the natural laws. It directly correlates with central nervous system (CNS) status - that is with its anatomical and functional adequacy. Motor development in a healthy child is determined by genetically established developmental patterns and environmental stimuli at the same time (1). Understanding normal motor development in newborns and infants and its clinical manifestation regarding motor activities is necessary for the detection and interpretation of certain developmental deviations (2). Developmental deviations are more common in newborns at neurorisk. A newborn at neurorisk is a baby born after a variety of risks during pregnancy. About $10 \%$ of newborns are considered to be at neurorisk (2).

Complications in newborns with neurorisk may be short- and long-term ones. Short-term complications are related to respiratory, cardiac, and gastrointenstinal complications. Long-term complications of the newborns, such as minor neurological dysfunction (MND) and cerebral palsy (CP) are particularly distinguished. Neurological assessment of newborns in everyday clinical practice includes classical neurological examination, scales and tests for discrimination, detection, elimination and evaluation of neurological deficits, as well as advanced diagnostic procedures, such as endocranial ultrasound (US) and mag- 
netic resonance imaging (MRI). All the aforementioned methods are of great importance in everyday clinical practice. They allow rapid detection of the CNS damage and rapid establishment of the diagnosis as well, but they share a common defect, which is the inability to adequately predict neurological deficit.

\section{Prechtl's method-qualitative assessment of spontaneous motor activity in newborns and infants}

Heinz Prechtl, an Austrian neurophysiologist and professor, developed a standardized method for early identification of neurological anomalies in newborns and infants after several decades of research. This method is based on qualitative assessment of spontaneous motor activity (SMA). All the present studies have confirmed that Prechtl's method has high sensitivity and specificity in detecting neurological anomalies in newborns and infants, especially for MND and CP.

Prechtl started his research in the 1960's. He believed that motor activities of newborns and infants are rhythmic and cyclic, both in the intrauterine period and following birth, as confirmed by later studies. He also concluded that rhythmic locomotion patterns are generated at low levels of the CNS, in the bipolar cells of the spinal cord, known as central pattern generator (CPG). When activated, CPG produces patterns of rhythmic activity without receiving any sensory stimulus or descending stimulation from higher control centers. Examples of CPGs include central mechanisms for breathing, sucking, swallowing, and for locomotion crawling, walking and swimming.

Prechtl's studies have advanced rapidly since the introduction of ultrasound diagnostics and its intensive application in clinical practice. It has revealed important facts regarding intrauterine fetal motor activity. Prechtl identified whole-body movements in the period of $9^{\text {th }}$ and $10^{\text {th }}$ gestational week (they can clearly be seen with a transvaginal probe) and called them 'general movements' (GMs) (3).

\section{General movements (gms)}

Apart from the fact that general movements are endogenously generated, it is important to note that they are present from early foetal life and persist until 5 or 6 months after term. GMs are complex, they involve all parts of the body in a variable sequence of all the segments of upper and lower extremities, head, neck, and trunk movements. Their intensity, force and speed, wax and wane, show that there is a sequence of involved body parts movements and gradual beginning and end. Changes in the direction of movement make them look variable, complex and elegant. Up to term age GMs are called foetal or preterm movements by Prechtl. At term age until about 6 (sometimes 9) weeks post-term age he named emerging GMs "writhing movements" (wriggling, twisting, stretching). These movements are characterized by moderate amplitude and moderate speed. Their form is elliptical, giving the impression of having a writhing characteristic. At 6 to 9 weeks post-term age, writhing movements gradually disappear and new GMs emerge, called by Prechtl "fidgety" movements (restless, uneasy). "Fidgety" movements are small movements of moderate speed and variable acceleration of the head, neck, trunk, and limbs, primarily involving their distal parts (radiocarpal and talocrural joint). They are manifested continually in the awake infant, except during crying. These movements can be seen as early as 6 weeks post-term, but they usually occur around 9 weeks and are present until 20 weeks or a few weeks longer. After that, voluntary and antigravity movements occur and dominate (3).

\section{Pathological patterns of general movements}

When it comes to newborns and infants with CNS damage, their SMA patterns change in comparison to infants with an intact brain. The studies conducted on SMA in foetuses with CNS damage reported that the character of SMA changes towards abnormal patterns and various forms of the CNS damage were confirmed after birth in these subjects. These studies show that SMA assessment may be a window into the CNS integrity. In infants with compromised CNS, the quantity of movements does not change in comparison to healthy population, but the quality of movements does. If the nervous system is impaired, SMA loses the characteristic complexity and variability. Prechtl classified abnormal writhing movements into three groups:

1. Poor repertoire writhing movements (PR) (4),

2. Cramped-synchronized writhing movements (CS) (5),

3. Chaotic writhing movements (Ch).

Prechtl described abnormal fidgety movements as:

1. Absent fidgety movements (F-) (6),

2. Abnormal fidgety movements (Ab F).

Poor repertoire writhing movements (PR) occur during preterm, term age and early post-term period. This model of writhing movements is characterized by less variability and the sequence of movement components that are monotonous and do not occur in a complex way, unlike their presentation in normal writhing movements. A newborn starts a movement, but does not complete it, giving the impression of an interrupted sequence. PR is more common in children with brain abnormalities. The predictive value of these movements is low. Later in life they can be followed by either normal or pathological motion patterns.

Cramped synchronized writhing movements (CS) occur from preterm period onwards. This type of pathological writhing movements is characterized by simultaneous contraction and relaxation of the trunk and upper and/or lower limb muscles. If these abnormal movements are carefully observed and if they exist over several weeks, they may be of great importance in predicting definitive neurological outcome in a newborn (5). These movements are of high predictive value for the development of $C P$, especially if they persist even after 9 weeks PMA.

Chaotic writhing movements (Ch) are abrupt, large amplitude movements of upper and lower 
limbs that are in chaotic order without any fluency or regularity. Chaotic movements can be observed in preterm, term, and early post-term period. Newborns with chaotic movements often develop cramped synchronized movements a few weeks later (3).

The absence of fidgety movements (F-) has high predictive value for later development of neurological impairments (6). In case fidgety movements do not occur in the period from 9-20 weeks postterm, there is a high probability of spastic and dyskinetic cerebral palsy development at a later age. If cramped synchronized movements persist during $3^{\text {rd }}$ and $4^{\text {th }}$ month or longer, fidgety movements do not occur.

Abnormal fidgety movements $(\mathrm{AbF})$ resemble normal fidgety movements, but their amplitude and speed are moderately or greatly exaggerated. Abnormal fidgety movements are rare and their predictive value is low.

\section{Assessment of spontaneous motor activity in newborns and infants}

The qualitative assessment of SMA in newborns and infants can only be performed by a certified examiner for this examination technique. Training courses for the qualitative assessment of SMA are educational programmes conducted by licensed tutors. After the verified completion of the training for the application of this method of evaluation, the interobserver agreement on pattern recognition of SMA in newborns and infants is $89-93 \%$ (3).

The simplest way of observation and assessment of SMA is by direct naked eye observation of the movements. Of course, higher reliability of the assessment is achieved when SMAs are evaluated by means of video recording, since it enables multiple evaluations during playback of the video recording. Adequate behavioural state of a newborn required for proper SMA observation includes eyes open, absence of crying, irregular respirations and general movements present (8).

\section{Conclusion}

The usability of the Prechtl Method is also proved by the fact that no studies have confirmed so far that normal general movements are followed by $\mathrm{CP}$ as a neurological outcome, on condition there were no serious interval complications. There are no cases with false negative findings. A study observing SMA in children with Rett's syndrome showed that PR may be indicative of later development of both MND and CP (9). The occurrence of CS "writhing" movements during preterm and early post-term period, as well as the absence of 'fidgety' movements in infants is predictive of spastic cerebral palsy, while abnormal "fidgety" movements are not predictive of $\mathrm{CP}$, but they are associated with MND later in life (10).

Thanks to the Prechtl Method it is possible to predict normal neurodevelopmental outcome with high probability by using observation and detection of SMA normal patterns in newborns and infants. Also, by observing and detecting pathological patterns of movement, it is possible to recognize specific neurological symptoms in prenatal period (US diagnostics), or after birth in preterm and term neonates, which are excellent indicators of later development of CP $(11,12,13,14)$. Early detection of MND and CP symptoms has enormous clinical significance since it enables timely inclusion of children into neurodevelopmental treatment, thus contributing to the improvement of motor functional status at a later age, taking into account a biological phenomenon known as "brain plasticity".

Since there are only 6 medical doctors in Serbia with a certificate of reliability in assessing SMA using the Prechtl Method, the aim of this paper was also to point out the necessity of including more physicians in the field of pediatric pathology into educational programme for early recognition and timely treatment of neurological abnormalities in children. 


\section{References}

1. Dimitrijević L, Čolović H. Ometanje normalnog motornog razvoja u prvoj godini života. Acta Medica Medianae 2005; 44(3):53-7.

2. Mercuri E, Ricci D, Pane M, Baranello G. The neurological examination of the newborn baby. Early Hum Dev 2005; 81(12):947-56. [CrossRef] [PubMed]

3. Einspieler $C$, Prechtl $H$, Bos A, Ferrari F, Cioni G. Prechtl's method on the qualitative assessment of general movements in preterm, term and young infants. Mac Keith Press 2008;

4. Beccaria $E$, Martino $M$, Briatore $E$, Podestà $B$, Pomero G, Micciolo R, et al. Poor repertoire General Movements predict some aspects of development outcome at 2 years in very preterm infants. Early Hum Dev 2012; 88:393-6. [CrossRef] [PubMed]

5. Ferrari $F$, Cioni $G$, Einspieler $C$, Roversi MF, Bos AF, Paolicelli PB, et al. Cramped synchronized general movements in preterm infants as an early marker for cerebral palsy. Arch Pediatr Adolesc Med 2008; 156 (5):460-7. [CrossRef] [PubMed]

6. Einspieler C, Peharz R, Marschik P. Fidgety movements - tiny in appearance, but huge in impact J Pediatr 2016; 92(3 Suppl 1):S64-S70.

[CrossRef] [PubMed]

7. Einspieler $C$, Prechtl HF. Prechtl's assessment of general movements: a diagnostic tool for the functional assessment of the young nervous system. Ment Retard Dev Disabil Res Rev 2005; 11:61-7. [CrossRef] [PubMed]

8. Dimitrijević $L$, Bjelakovic B, Čolović $H$, Mikov A, Živković $V$, Kocić $M$, et al. Assessment of general movements and heart rate variability in prediction of neurodevelopmental outcome in preterm infants. Early Hum Dev 2016; 99:7-12. [CrossRef] [PubMed]

9. Einspieler $C$, Kerr AM, Prechtl HF. Abnormal general movements in girls with Rett disorder: the first four months of life Brain Dev 2005; (27):S8-S13.

[CrossRef] [PubMed]

10. Kodric J, Sustersic B, Paro-Panjan D. Assessment of General Movements and 2.5 years developmental outcomes: pilot results in a diverse preterm group. Eur J Paediatr Neurol 2010; 14:1317.

[CrossRef] [PubMed]

11. Olsen JE, Allinson LG, Doyle LW, Brown NC, Lee KJ, Eeles $A L$, et al. Preterm and term-equivalent age general movements and 1-year neurodevelopmental outcomes for infants born before 30 weeks' gestation. Dev Med Child Neurol 2018; 60:47-53. [CrossRef] [PubMed]

12. Einspieler C, Marschik PB, Bos AF, Ferrari F, Cioni G, Prechtl HF. Early markers for cerebral palsy: insights from the assessment of general movements. Future Neurol 2012; 7:709-17. [CrossRef]

13. Bosanquet M, Copeland L, Ware R, Boyd R. A systematic review of tests to predict cerebral palsy in young children. Dev Med Child Neurol. 2013; 55:41826. [CrossRef] [PubMed]

14. Øberg GK, Jacobsen BK, Jørgensen L. Predictive Value of General Movement Assessment for cerebral palsy in routine clinical practice. Phys Ther 2015; 95:1489-95. [CrossRef] [PubMed] 


\title{
ZNAČAJ PREHTLOVE METODE U ULTRARANOJ PREDIKCIJI NEUROLOŠKIH ABNORMALNOSTI KOD NOVOROĐENČADI I ODOJČADI
}

\author{
Dragan Zlatanović1,2, Hristina Čolović1,2, Vesna Živković1,2, Mirjana Kocić1,2, \\ Anita Stanković ${ }^{1}$, Jelena Vučić ${ }^{3}$, Nikola Bojović ${ }^{4}$ Maja Raičević ${ }^{4}$, Mlađan Golubovićs, \\ Ljubomir Dinić6, Tamara Stanković
}

\author{
${ }^{1}$ Klinika za fizikalnu medicinu i rehabilitaciju, Klinički centar Niš, Niš, Srbija \\ ${ }^{2}$ Univerzitet u Nišu, Medicinski fakultet, Niš, Srbija \\ ${ }^{3}$ Klinika za pedijatriju, Klinički centar Niš, Niš, Srbija \\ ${ }^{4}$ Klinika za dečiju hirurgiju i ortopediju, Klinički centar Niš, Niš, Srbija \\ ${ }^{5}$ Klinika za anesteziologiju i reanimaciju, Klinički centar Niš, Niš, Srbija \\ ${ }^{6}$ Klinika za neurologiju, Klinički centar Niš, Niš, Srbija \\ ${ }^{7}$ Centar za nuklearnu medicinu, Klinički centar Niš, Niš, Srbija \\ Kontakt: Dragan Zlatanović \\ Učitelj Tasina 25/3, 18000 Niš, Srbija \\ E-mail: dragan.zlatanovic@medfak.ni.ac.rs \\ draganzlatanovic1@gmail.com
}

Rana detekcija simptoma cerebralne paralize i minimalnog neurološkog deficita kod novorođenčadi i odojčadi od krucijalnog je značaja, jer omogućava pravovremeno uključivanje dece u neurorazvojni tretman, što doprinosi poboljšanju funkcijskog motoričkog statusa u kasnijem uzrastu, računajući na biološki fenomen "plasticiteta mozga". Konvencionalne metode neurološke procene novorođenčeta i odojčeta podrazumevaju neurološki pregled, kvantitativnu procenu motoričkih sposobnosti pomoću skala i testova, kao i korišćenje dopunskih dijagnostičkih neuroimidžing procedura. Sve nabrojane metode svakako su neophodne i u širokoj su kliničkoj primeni i služe za brzo postavljanje dijagnoze neuroloških oboljenja ili detekciju oštećenja centralnog nervnog sistema, ali imaju jedan zajednički nedostatak - nemogućnost adekvatne prognoze neurološkog deficita. Zahvaljujući Prehtlovoj metodi, koja se zasniva na kvalitativnoj proceni spontane motoričke aktivnosti, moguće je definisati specifične neurološke obrasce, čak i prenatalno kod fetusa, kao i postnatalno kod preterminskog ili terminskog novorođenčeta, koji su odlični pokazatelji kasnijeg neurološkog razvoja deteta. Cilj rada je revijski prikaz podataka iz literature o značaju i mogućnostima Prehtlove metode naspram drugih konvencionalnih metoda u ultraranom prepoznavanju rizične grupe novorođenčadi i odojčadi za razvoj trajnog neurološkog deficita - cerebralne paralize i/ili minimalne neurološke disfunkcije.

Prehtlov metod spada u najsenzitivniju i najspecifičniju kliničku dijagnostičku proceduru u proceni budućeg neurološkog ishoda rizične grupe novorođenčadi i odojčadi.

Acta Medica Medianae 2019;58(3):111-115.

Ključne reči: novorođenče, odojče, spontana motorička aktivnost, rana dijagnoza, cerebralna paraliza, Prehtlov metod 